\title{
Shifting sand, shifting livelihoods? Reflections on a coastal gold rush in Ghana
}

Article

Accepted Version

Hirons, M. (2014) Shifting sand, shifting livelihoods?

Reflections on a coastal gold rush in Ghana. Resources Policy, 40. pp. 83-89. ISSN 0301-4207 doi:

https://doi.org/10.1016/j.resourpol.2013.08.005 Available at https://centaur.reading.ac.uk/44173/

It is advisable to refer to the publisher's version if you intend to cite from the work. See Guidance on citing.

To link to this article DOI: http://dx.doi.org/10.1016/j.resourpol.2013.08.005

Publisher: Elsevier

All outputs in CentAUR are protected by Intellectual Property Rights law, including copyright law. Copyright and IPR is retained by the creators or other copyright holders. Terms and conditions for use of this material are defined in the End User Agreement.

www.reading.ac.uk/centaur

\section{CentAUR}


Central Archive at the University of Reading

Reading's research outputs online 
Resources Policy, 40, (2014), 83-89.

\title{
Shifting sand, shifting livelihoods? Reflections on a coastal gold rush in Ghana
}

\author{
Author: Mark Hirons \\ Author Details: Mark Hirons is at the School of Agriculture, Policy and Development, \\ University of Reading, UK. Email:m.a.hirons@reading.ac.uk.
}

\begin{abstract}
Artisanal and small-scale mining (ASM) is often characterised as rush-type activity undertaken by people looking to 'get-rich quick'. An alternative view posits ASM as poverty-driven activity which provides a valuable source of employment to a rural population where agriculture has failed to provide an adequate income. Against this dichotomy, this article critically reviews the short-lived, but high profile, gold rush which occurred on the beaches of Elmina, a fishing town in Ghana's Central Region. At its peak, more than 1000 people, including local fishermen and career miners from the Western Region and Eastern Region of the country, were mining on the beaches. Drawing on interviews with miners and local business owners, the analysis explores the dynamics of the rush and its implications for understanding the ASM sector in Ghana. The discussion highlights the challenges associated with managing resources in dynamic and heterogeneous contexts, reconciling separate and conflicting sectoral priorities and the need to go beyond simplified and dualistic representations of the sector.
\end{abstract}

Keywords: Artisanal and Small-scale Mining (ASM), Ghana, Elmina, Gold Rush, Livelihood Diversification

\section{Introduction}

Artisanal and small-scale mining (ASM) - the labour intensive extraction of minerals using little or no mechanisation - employs more than 100 million people worldwide, mainly in developing countries (ILO, 1996; Global Mercury Project, 2006). In addition to the valuable role it plays in livelihoods, it is a contentious activity due to its association with land degradation, mercury pollution, poverty and related social issues, and poor safety record (e.g. Hentschel, 2002; Dondeyne et al.,2009; Bose-Reilly et al., 2010, Hilson, 2012a; Hilson, 2012b). Despite the benefits that could potentially accrue to individuals and communities, and the reductions in environmental and social costs, associated with a well managed ASM sector, governments have consistently failed to formalise and regulate the sector effectively (Hilson and Potter, 2003; Hilson, 2007; Tschakert, 2009). Artisanal and small-scale mining has received proportionally less attention by national governments, development practitioners and academics than its importance in rural economies might suggest, and undoubtedly the resultant knowledge deficit has contributed to the sector's poor management (Hilson and Maponga, 2004; Clifford, 2012). 
This paper aims to contribute towards an increased understanding of the sector by examining an episode where miners flocked onto the beaches at Elmina, a fishing town in Ghana's Central Region. The analysis draws on 20 interviews with miners and local business people and ethnographic observations undertaken on two field trips, one in December 2011 and another in August 2012. The case study is presented predominantly from the perspective of the miners, but the subsequent reflections and discussion unpack the prevalent issues against a broader background.

The first section contextualises ASM in Ghana, outlining how the sector has developed and introduces key contemporary debates regarding livelihood diversification and the importance of perceptions in policy-making. The case of Elmina is presented against this background, outlining how the rush developed, was addressed by government and local authorities through security services, and the situation which followed. The subsequent discussion reflects on what the Elmina episode means for ASM in Ghana, examining in particular issues regarding the management of resources in dynamic and heterogeneous contexts, reconciling separate and conflicting sectoral priorities and the need to go beyond dualistic representations of the sector. The discussion also highlights the challenges with co-ordinating a coherent and broad response from the variety of authorities who influence resource exploitation.

\section{Artisanal and Small-Scale Mining in Ghana: Development and Discourses}

Contrary to popular depictions of the sector, ASM in Ghana is both a deeply rooted activity, and characterised by dramatic, often chaotic, growth. Over the preceding century, ASM activities in the country have been influenced by colonial and post-colonial interventions in the minerals sector and economy more broadly. This section briefly outlines the historical development of the sector and the current state of ASM in Ghana, reviewing in particular the debates on livelihood diversification and unpacking the importance of how the sector is perceived by policy-makers.

Extraction, processing and trading of mineral wealth has been a feature of rural economies in Ghana and throughout sub-Saharan Africa for more than 1000 years (Hilson, 2002; Grant et al., 2011). For the majority of this time, mining has been characterised by the rudimentary techniques which continue to dominate contemporary ASM. The most profound shift in the dynamics of the minerals sector in the region occurred during the $19^{\text {th }}$ century when, facilitated by rapid colonial expansion, European mining companies increased their attempts to establish operations in the area known then as the Gold Coast. These ventures unanimously failed to become productive companies (Silver, 1981; Ofuso-Mensah, 2011), but their presence precipitated the establishment of an informal and disorderly market in mining concessions ${ }^{1}$. The effect of this still resonates in contemporary debates on resource management; the concession covering the resource-conflict riddled town of Obuasi in the Ashanti Region, for example, was first instituted in early 1897 (Ayensu, 1997).

Despite the persistent resistance of small-scale miners to foreign mining companies in the early $20^{\text {th }}$ century, which contributed to sustained low levels of output, colonial authorities continued to pursue the extraction of gold. This included another intensive push to increase production after World War I, but this only temporarily rejuvenated gold production. The deterioration of mining

\footnotetext{
${ }^{1}$ Formalised in 1900 in the Concession Ordinance
} 
operations led to a post-World War II drop in output, and the eventual nationalisation of all but one of the country's mining companies (Hilson, 2002).

Chronic problems with the financial, institutional and legal frameworks associated with the sector, and the country as a whole, led to the inception of the International Monetary Fund (IMF) supported Economic Recovery Programme (ERP) in 1983.The ERP has had a profound impact on the character of the minerals sector in Ghana, not only rejuvenating the large-scale sector, but also inadvertently encouraging the growth of the small-scale sector, which resulted partly from the influx of retrenched civil servants (Banchirigah, 2006).

Reforms to the minerals sector have undoubtedly led to improvements in its economic productivity. Attempts to attract foreign investors through a series of tax breaks, exemptions and variable royalty rates were successful; in the period 1983-1998 US\$4 billion were invested in rehabilitation, exploration and establishing new mines. The country's mining sector now contributes about $40 \%$ of foreign exchange income, and around $5 \%$ of gross domestic product (GDP) (Aryee, 2001; Ghana Statistical Service, 2009). These successes are also reflected in other sectors, such as forestry and cocoa production.

The ERP and subsequent rounds of structural adjustment, however, have been criticised for the profoundly negative economic effect on the wider population. Depreciating currencies, reduced government spending, and removal of subsidies and price supports for key food and energy commodities compounded issues raised by reduced employment, particularly in the public sector (Hutchful, 2002; Baah-Boateng, 2004; Hilson and Potter, 2005). Boafo-Arthur (1999), for example, estimates that unemployment as a result of the programmes led to the retrenchment of between 100,000 and 200,000 public service workers.

The concurrent failure and persistently tenuous nature of small-holder farming in Ghana, as well as elsewhere in sub-Saharan Africa, has led to widespread deagrarianisation (Bryceson, 1996; Barrett, 2001). Individuals and communities who are unable to adequately support themselves through rainfed agriculture under increasingly globalised and liberal markets have augmented their incomes by engaging with ASM. The nascent literature on these phenomena suggest that it underlies much of the growth observed in the sector over the preceding decades (Banchirigah, 2006, Banchirigah and Hilson, 2009; Bryceson and Jønsson, 2010).

Conservative estimates suggest that ASM in Ghana now contributes more than $20 \%$ of all gold mining revenues in the country and employs more than one million people directly (Tetteh, 2012), although there is considerable uncertainty with all employment estimates in the sector. In addition to the direct benefits accruing from the sector, ASM also supports a host of downstream industries such as provision of food and accommodation, mechanical support and transport, making it a vital component of rural economies and a viable location for a range of 'small-time' investors (Kumar and Amaratunga, 1994; Nyame et al., 2009). Activities in the sector are not, however, generally antagonistic towards agriculture, and in many instances the activities are complementary with individuals mining seasonally to coincide with lulls in the agricultural season (Hilson and Garforth, 2012).

The discourse that posits ASM as a valuable source of income for poor individuals and communities who are seeking to diversify their livelihoods in the face of unviable agricultural operations has 
gained considerable currency in recent years. It has been promoted, however, largely in response to suggestions that the sector and its participants were viewed as agents looking to 'get-rich quick', without regard for social or environmental consequences. This position draws credence from the continuing degradation of mining areas and the growing use of excavators costing 8000 cedis $^{2}$ per day to hire. The neglect and marginalisation of the sector, resulting from this widely held perception in policy-making circles, has merely served to compound these issues which remain inadequately addressed (Tschakert and Singha, 2007; Hilson, 2009).

The formalisation process in Ghana, for example, has been widely criticised for being financially and bureaucratically burdensome such that only an estimated 10 per cent of ASM activities in Ghana are currently licensed under the 1989 Small-Scale Gold Mining Law and the revised Minerals and Mining Act 2006 (Hirons, 2013). The formalisation process has been further undermined by an underappreciation of the intertwined nature of formal and informal operators, political leniency and law enforcement corruption (Teschner, 2012). The contemporary informal dynamics in the sector, where decision-making processes are dominated by local land owners and chiefs (Nyame and Grant, 2012) ${ }^{3}$, give the impression of activities being beyond the control of government. This contention is also reflected in findings that alternative livelihood programmes, such as rearing grasscutters, beekeeping or snail farming, have failed to encourage people to abandon ASM, principally due to the unattractiveness of, and uncompetitive incomes provided by these promoted alternatives (Tschakert, 2009; Hilson and Banchirigah, 2008).

Contemporary policy debates have revolved around the underlying drivers of growth and the motivations of miners to engage with the sector. Is growth led by greedy criminal gangs looking to get-rich quick, or by poor and marginalised individuals attempting to augment their precarious livelihoods? This prevailing greed-need discourse has become increasingly polarised and its prominence masks the reality that the sector is characterised by a wide range of actors with a variety of motivations for involvement. The sector is an engine of growth and income generation, burgeoning chaotically and predominantly informal, but is also deeply rooted, highly organised and intimately associated with poverty.

Against this context, this paper goes on to outline the case of the Elmina gold rush and demonstrates how it illustrates the need to recognise the complexities of the sector, develop more nuanced and less dualistic representations of its activities, and reiterates the importance of managing natural resources across industries.

\section{The Case of Elmina}

\subsection{Background - Characterising Resource Use in Elmina}

Even before the arrival of the Portuguese, gold was an important part of the fabric of society in the ancient Kingdom of Ghana. Gold winning on the beaches, particularly near streams and after heavy rains, was commonly undertaken by women and children. It was the auriferous inland areas, however, which attracted the attention of European colonisers. Motivated by a shortage of gold in

\footnotetext{
${ }^{2}$ About US\$4000

${ }^{3}$ As well as a recent influx of Chinese workers and operators
} 
Europe, the Portuguese colonised current-day Elmina ${ }^{4}$ as part of a wider expansion into West Africa, the aim of which was to gain control of trade along the 'gold coast' (Hilson, 2002). The Castle of St George was established in Elmina in 1482, principally as a coastal trading post for gold originating from regions inland from Elmina as well as other goods, but subsequently gained notoriety as a slave fort.

The lucrative trade along the coast, increasingly focussed on slaves, was highly contested during the sixteenth and seventeenth centuries. The Dutch ousted the Portuguese from Elmina in 1637 and made the town the capital of their colony (Teye, 2002). They dominated trade in the area until the fall of the slave trade at the beginning of the nineteenth century. Dutch rule came to an end when the British established the Gold Coast Colony in 1872 until independence in 1957.

The Castle of St. George, now a United Nations Educational, Scientific and Cultural Organisation (UNESCO) World Heritage site, is today the centre-piece of Elmina's tourism industry, which along with fishing constitutes the backbone of the local economy. In addition to these activities the town is noted for its salt-mining and sand-winning. Recently, the sand-winning activities, which are undertaken to provide the materials to make building blocks, have come into conflict with tourism due to the damage caused to beaches that front the town's hotels (Daily Graphic, 2012; Ghana News Agency, 2012). One local business man estimated in an interview that for about three years an average of 40 trucks of sand a day were removed from the beach adjacent to his hotel resulting in the loss of more than $30 \mathrm{~m}$ of land and 80 coconut trees. He bemoaned the lack of response from government agencies, and noted the importance of traditional leaders in maintaining the activity. Traditional authorities in the town purportedly earn 15 cedis per truck of sand ${ }^{5}$, a valuable source of revenue considering that they do not receive any royalties generated through tourism.

The persistent antagonism between sand-winning and tourism reflects the poor relationship between state and traditional authorities which appears to inhibit the effective use of revenues. The Komenda-Edina-Eguafo-Abrem (KEEA) Municipal Assembly, of which Elmina is the capital, has received more than 15 million euros in grants to develop its tourism industry. But despite this injection of capital, and the revenues generated through sand-winning, the town has experienced little meaningful development over the preceding decade (Koutra and Edwards, 2012).

The broadly perceived lack of distributive fairness regarding revenue generation may have contributed to the unexpectedly ebullient response to the (re)discovery of gold on the town's beaches. The Elmina gold rush garnered significant attention. The following sections outline the dynamics of the rush and the situation in late 2012 before discussing its wider implications.

\subsection{The Gold Rush}

The Elmina gold rush had an inauspicious genesis; purportedly, a miner visiting the town for a funeral took a sample of the 'black sand' back to his hometown of Akwatia ${ }^{6}$ and confirmed the

\footnotetext{
${ }^{4}$ The name Elmina is derived from the Portugese 'Mina', meaning 'the mine'.

${ }^{5}$ Which amounts to more than US\$11,000 per month.

${ }^{6} \mathrm{~A}$ significant mining town in the Eastern Region noted primarily as a diamond mining and trading town but has recently experienced a growth in gold mining (Hilson, 2010).
} 
presence of gold. Reports from miners in Elmina suggest that from July until November, only a few people were engaging in galamsey ${ }^{7}$ on the beaches. Momentum gathered during November, and by the middle of the month, approximately 1000 people were mining on Elmina Beach and the adjacent Ayisa Beach ${ }^{8}$. The rush was able to develop so quickly largely because of the availability of labour, the extremely rudimentary techniques used ${ }^{9}$ and because mobile information and communication technologies (ICTs) permitted the rapid spread of information regarding the discovery (Grant et al., 2013). Furthermore, the beaches were not considered by the miners to be owned by anyone, negating the need for them to negotiate with land owners or users ${ }^{10}$. This is unusual in Ghana's ASM sector because, as Nyame and Grant (2012) note, traditional authorities effectively represent customary land owners and as a result play an important role in distributing areas for mining.

The scale and location of the rush meant it received substantial media coverage. News reports (Water resources Commission of Ghana, 2011; Owusu-Darlington and Dapaah, 2011), substantiated by interview respondents, noted the broad-based involvement in activities. Although reports of school-children still in uniform leaving school and engaging in mining and policemen leaving post to mine were particularly eye-catching, the majority of miners were either fishermen from Elmina, a group dominating the local demography, or miners from better known ASM areas in the Eastern Region and Western Region.

Fishermen interviewed in December said they were mining because it gave them substantial increases in income; they reported earning their weekly fishing income, approximately 20 cedis, in a day mining. They also recognised the risks associated with mining, but as on miner argued in an interview, 'some days you can mine and not find gold, but in fishing, it is the same'11. Another reason the mining was attractive was that it was not considered necessarily mutually exclusive with fishing; several of the miners interviewed would go fishing in the morning and mine in the afternoon. Fishing trips would sometimes last several days, but the incentive to do both had meant some fishermen reduced or in some cases stopped fishing altogether in order to accommodate mining.

Due to the extremely rudimentary techniques being used, most miners were able to operate without sponsors, although, some of the miners reported being sponsored by more experienced miners and sponsors from mining towns such as Tarkwa, who were also acting as buyers. Some miners expressed frustration at buyers who were buying at prices considered to be too low, seemingly exploiting the lack of knowledge of the industry by many local participants, and said instead of selling in Elmina, they would take their gold back with them to their hometowns.

The high-profile nature and location of the rush meant that numerous concerns were raised rapidly by government and local authorities, including, the economic and social impact of reduced fishing,

\footnotetext{
${ }^{7}$ Meaning gather them and sell. The term can be used as a verb or a noun, and is sometimes used to distinguish between legal, concession owning operations (called small-scale mining) and illegal operations. ${ }^{8}$ These beaches flank either side of the Castle of St. George.

${ }^{9}$ Miners requiring only a bucket, spade and some 'carpet' (material placed on a bench on an approximately $30^{\circ}$ slope designed to trap the heaviest particles, including gold, when sand is washed over it).

${ }^{10}$ Legal tenure of beaches in Ghana reflects the pluralistic nature of land ownership in the country which is generally characterised by a matrix of vested in stool lands, private ownership and usufruct right holders (Nyame and Blocher, 2010). Minerals 'in their natural state', including the gold found on the country's beaches, are vested in the state and are therefore under the jurisdiction of the Minerals Commission and the Geological Survey Division.

${ }^{11}$ Interview with a small-scale miner in Elmina on 16.12.12.
} 
reduced protection of the freshwater lagoon by degraded beaches and mercury use. Warnings over mercury use had been broadcast on radio which some miners were heeding. But despite these warnings several miners were unaware of the issue, and mercury was observed being used on the beaches. In addition to these concerns, the Ghana Geological Survey was arguing that activities should stop until it could prove whether or not the presence of gold on the beach represented a viable, minable deposit. These factors precipitated a security intervention by the police. However, as the following section outlines, it was not a definitive intervention and activities remained, albeit, at a much reduced volume.

\subsection{Establishing a Cyclical Pattern of Intervention}

The government promoted intervention by security services purportedly because the Elmina deposit is unviable, and therefore any activities have a net cost, a stance which was supported by the paramount chief. This cooperative stance developed ostensibly in response to criticisms faced by both sets of authorities over sand-winning in the town. But while there are plenty of justifiable reasons to halt activities on the beach, the one provided by the government is nonsensical. The continual presence of miners of the beach illustrates how policy-makers systematically ignore the perspective of the miners; that is, simply, that mining delivers benefits. If it did not, miners would not continue working on the beach under the recurrent threat of police operations to arrest them and confiscate their equipment.

Clearly, however, the threat of arrest has changed the economic rationale for decision-making amongst miners and fishermen. By mid-December, after several weeks of police sweeps, about six miners had been arrested and only 100 miners were left operating, focussed on Ayisa Beach. Visits to Elmina in Feburary, June and August confirmed the continual presence of miners on Ayisa Beach, although in dwindling numbers.

This pattern of intervention, where police sweep and clear miners from the beach, usually between one and three times a week, after which miners return for a few days before the next police sweep, has become the established norm for the area. Over the course of the nine-month period where the site was visited, this had a distinct impact on both the numbers of mines, which gradually reduced, but also the characteristics of miners who were involved.

In December, many of the miners were from mining regions and were seeking to maximise benefits and most argued that they were mining to increase their income, evidenced by their stated desire to dredge the lagoon and mine it. Although many of the miners had already begun to drift back to fishing or mining elsewhere, some were defiant. One miner who was interviewed said,

We have courage to mine, we will stay here and mine. If the police come, we don't fear them, when they come we just go swimming' ${ }^{12}$.

Several miners interviewed in December also reported mining during the night to avoid police action, a tactic employed by galamsey to circumvent disruption throughout the country, while those

\footnotetext{
12 Interview with a small-scale miner in Elmina on 16.12.11.
} 
that stopped mining cited police intervention as their primary cause. One miner, interviewed on the $16^{\text {th }}$ December on the beach and on the $17^{\text {th }}$ December at the Bus station at Cape Coast, said

'I'm leaving [Elmina] now, it is too much. They confiscated my equipment yesterday. So I'm going back to my place in Eastern Region ${ }^{13}$.

Interviews conducted in August painted a very different picture, with miners more typically saying they were mining 'because we don't have money'. As one miner said in an interview,

'We are into this because there are no alternatives here and as a man I have to also force to make ends meet by involving myself in what is available. I make blocks too ${ }^{\prime 14}$.

These miners were characterised by being on the fringes, or marginalised in society. For example, instead of being fishermen or miners elsewhere in the country, they were carriers in the fish market, cooling stations or block makers. It appears that the cyclical police intervention has led to gradually decreasing numbers of miners who are increasingly marginalised and poor individuals.

These dynamics, particularly the continued presence of mining in spite of relatively sustained police operations, raise several issues to reflect on. The following section goes on to unpack what the Elmina case reveals about managing dynamic and heterogeneous resource use contexts, the challenges of reconciling potential competing sectors in a locality, and the limited and simplified scope of greed-need discourses.

\section{Reflections and Discussion}

The gold rush on the beaches of Elmina, which began during November 2011, never seriously threatened to derail the town's economic mainstays of fishing and tourism, but it did serve to heighten interest in the ASM sector and the town's development more generally. The rush, followed by the establishment of a cyclical pattern of police intervention, supported by state and traditional authorities, highlights several important issues which are pertinent to the sector, both specifically and in general terms. This section discusses these issues under three headings, 1) Dealing with dynamic and heterogeneous contexts, 2) ASM and the challenge of cross-sector co-ordination, and 3) Adding nuance to the greed-need discourse.

\subsection{Dealing with dynamic and heterogeneous contexts}

The formalisation process for ASM concessions in Ghana is criticised for being excessively bureaucratic and financially costly; in effect the process is unresponsive considering the speed at which ASM sites develop. The case of Elmina demonstrated very publically how rapidly sites can grow. But the explosion in numbers of people mining is not unique; a recent example of an

\footnotetext{
${ }^{13}$ Interview with a small-scale miner in Cape coast on 17.12.11. This respondent also showed a video on his mobile phone of the river dredging operation demonstrating the relative professionalism of some of the miners involved in the Elmina rush.

${ }^{14}$ Interview with a small-scale miner in Elmina on 04.08.12.
} 
exploding ASM site is Ntrotroso where approximately 3000 miners arrived in a matter of weeks at a recently discovered ASM site in the Brong-Ahafo Region.

The Elmina case also demonstrates the diversity of people choosing to engage in ASM. Career miners ${ }^{15}$ worked alongside fishermen and other locals with no previous experience who quickly acquired the simple skills and techniques required. This is illustrative of the low barriers to entry which has contributed to the growth of ASM nationwide. It is evident that interventions or policies which treat miners as a homogeneous group which is likely to respond to various economic incentives similarly will never comprehensively address the sector's issues.

This notion is highlighted by the impact of cyclical police intervention on the broad demography of miners at Elmina. The interventions persuaded career miners to return to their activities on ASM sites in the Eastern Region and Western Region relatively quickly. But it has not dissuaded poorer members of the Elmina community from continuing work, and several people who have stopped mining hope to be allowed to resume work in the future.

While this feature is illustrative, Elmina is unique regarding the ostensible lack of land ownership over the beaches and the notable absence of sponsors which characterises most ASM activities in the country. Nonetheless, it is evident that targeted interventions which use different approaches to address the drivers of different actors are likely to be most effective. For example, arresting and fining an individual for mining could be extremely damaging financially for a poor miner, or, it might amount to little more than an inconvenience to a wealthy sponsor. One miner described in an interview the financial consequences of being arrested,

Sometimes they ask for about GHC500 before you are released. There is a boy here who came from somewhere to do this job. He was arrested and is still in their custody. The police are requesting $\mathrm{GHC} 2500$ before his release ${ }^{16}$.

The variety of different actors involved in mining requires policy-makers, law enforcers and the judiciary to have a more nuanced understanding of how the sector works and a more case-sensitive recognition of what constitutes a reasonable and effective deterrent. This may also entail an improvement in the law itself (Teschner, 2012). This is particularly important at lower-profile sites where the impetus for regular sweeps does not exist, in these instances it is imperative that the heterogeneity of actors is appreciated in law and policy.

Traditional authorities represent another important source of authority regarding mining, and landuse more generally. Their role is often neglected, in part because of political sensitivities and controversy. Part of the effectiveness of police interventions in Elmina is due to the united position presented by state and traditional authorities. This is evidenced by the ineffectiveness of the state apparatus in addressing sand-winning along the coast, an activity endorsed by the paramount chief. The un-quantified, but considerable, environmental costs associated with sand-winning and mercury use on beaches suggest these arrangements are politically rather than ecologically derived. It does, however, illustrate the significance of traditional authorities whose influence is not particularly

\footnotetext{
${ }^{15}$ The term career miners is used to refer to miners at Elmina who were experienced miners working primarily on inland ASM sites.

${ }^{16}$ Interview with a small-scale miner in Elmina on 04.08.12.
} 
amenable to policy, but still of considerable importance (Ubink and Quan, 2008). In order to improve natural resource management, integrating and co-ordinating traditional and state authorities appears imperative.

\subsection{ASM and the challenge of cross-sector co-ordination}

Traditional authorities are also important because they can influence decisions across sectors, a factor which state agencies and donors, often operating in sectoral silos, state as an impediment to sound resource management (Mee et al., 2008). Elmina is endowed with several resources, most notably fishing and tourist attractions, but also salt mining and sand-winning. These resources, particularly tourism, operate in disconnected ways, and as a result, have not delivered the broad development infrastructure which might be expected. The use of Ayisa Beach as a communal toilet, for example, is a pertinent ocular and olfactory reminder of the poor sanitation in the town. While the influx of miners from outside onto the beaches has little to do with the disconnect between the town and its tourism, the enthusiasm of local people, and more importantly, the persistence of locals engaging with ASM on the beaches adjacent to a UNESCO World Heritage site points to a broad dissatisfaction with the management of the tourism industry and its revenues.

Compared to sand-winning in the locality and other ASM areas nationwide, ASM at Elmina has been relatively well contained. As suggested previously, even though their motivation and reasoning is opaque, the co-ordination between the chief and government agencies has contributed to a more coherent and consistent outcome. Relative to sites which have required considerable investment to establish and produce more substantial quantities of gold, ASM in Elmina is less susceptible to corruption undermining security interventions. However, this should not detract from the lesson demonstrated here; policy-making and interventions need to account for all relevant authorities in order to co-ordinate effectively resource management across sectors. More broadly, the gold rush in Elmina and the continued presence of people mining on the beaches highlights, again, how important ASM can be as an alternative source of livelihood. While the newsworthy reports of the episode focused on the rush, a more longitudinal examination accentuates the role ASM can play as a viable livelihood option amongst the poorest.

\subsection{Adding nuance to greed-need discourse}

Contemporary growth in the Ghanaian ASM sector is often understood in a very dichotomous way. It is either framed as an activity driven by greedy criminals looking to get-rich quick, as it was in the case of Elmina (Hilson, 2009; Owusu-Darlington and Dapaah, 2011). But, on the other hand, it is framed as being as a deeply-rooted activity undertaken by a poor and needy population for whom structural adjustment packages, Poverty Reduction Strategy Papers and agricultural reform has failed to provide a viable livelihood (Banchirigah, 2008; Hilson and Garforth, 2012). The importance of perception to the sector was illustrated by a lengthy discussion at a recent policy forum about whether it should be seen as poverty alleviating or wealth creating. While this debate is largely about semantics, it suggests that it is increasingly recognised that the public and policy perception of the sector requires more nuance. 
The Elmina rush, consisting of both fishermen and miners from elsewhere in the country, demonstrates that some miners are motivated by increases to income. These miners were deterred fairly easily, and returned to fishing or mining elsewhere in the country with relative ease. Contrarily, after nine months of a cyclical pattern of mining, police sweeps, and returns to mining, mining was still occurring on the beaches. This illustrates what is found throughout Ghana, that neither the greed, nor the need, discourse sufficiently explains the reality of ASM sites.

What policy-makers do not seem to sufficiently recognise is that the adoption of a cost-benefit mindset does not adequately account for the variety and complexity of accounting for costs and benefits in the sector. Policy-makers want to know what the opportunity cost is for galamsey; it ranges by several orders of magnitude from effectively zero for the poorest participants who, using the most rudimentary methods, can engage at very little to no cost, to sponsors and land owners who may have invested tens of thousands of dollars into developing a site. This is not merely an economic problem though. As Martinez-Alier (2001) points out, these issues are rooted in the problematic, power-laden and technocratic language of valuation which dominates policy discussions. Until policy-makers stop thinking about participants in ASM as a homogeneous group of actors with a fixed opportunity cost, interventions and policies will fall short of managing the sector effectively.

The common theme running through interviews with miners at Elmina was dissatisfaction. As well as the evident failure of development initiatives in the area, this points to a failure of decentralisation initiatives to provide local legitimacy to development interventions, particularly with tourism in the case of Elmina. An appreciation of this dissatisfaction and its roots, rather than the usual rhetoric of greed or need, might be a more fruitful basis for intervening in the sector. Furthermore, the sense of dissatisfaction remains; many people in Elmina are still hoping, forlornly, that they will be allowed to return to mining on the beach in the future. Looking forward, the situation at Elmina remains potentially volatile while these issues remain unaddressed.

The broader context of Elmina suggests that it is important that traditional authorities, district assemblies and national government agencies and their regional district offices are co-ordinated and decentralisation must improve so relevant and timely information can be collected. But barriers to this run deeply, and cannot be amended by policy. Denney (2013), for example, highlights the challenge of integrating programs rooted in liberal democracy with chiefly institutions which have often been characterised by autocracy, poor transparency and a lack of accountability mechanisms (see also Addo-Fening, 2008). Ubink and Quan (2008) further note how the separation of state and traditional authorities over land tenure is so revered that it inhibits frank and rigorous examination of land-based governance issues among policy-makers. These issues are intensely political, but nonetheless need urgent attention in order to improve the management of the country's natural resources.

\section{Concluding Remarks}

Trends towards deagrarianisation and livelihood diversification have set the context for the contemporary burgeoning growth of ASM in Ghana. The sector has become increasingly high profile due to its association with wealth creation, as well as poverty and environmental degradation. The 
arrival of more than a thousand small-scale miners on the beaches at Elmina, one of the country's leading tourism destinations, raised the profile of the sector further.

The rush, which initially gathered impetus due to the influx of career miners from inland regions and the involvement of local fishermen, was relatively short-lived. A cooperative stance between traditional and state authorities against the activities, enforced by security services, ensured that the majority of miners returned to their previous occupations. While this lends weight to the assertion that galamsey is a greed driven activity, the sense of dissatisfaction, aimed primarily at poorly managed revenues from tourism combined with the continued presence of poorer individuals mining, lends credence to the notion that the sector is an important livelihood source for the poor, and that it is a vital component of livelihood diversification in the country.

In addition to illustrating the inadequacy and inaccuracy of dualistic representations of the sector, the Elmina case demonstrates the heterogeneity of ASM sites. Even though the mining at Elmina is as rudimentary and simple as ASM can be, there are still a host of actors engaging with the activities and multiple actors associated with decision-making. The case reiterates the importance of chiefs and other local authorities and suggests the need for a renewed examination of the decentralisation process for natural resource management to increase the legitimacy and efficacy of both state and traditional forms of regulation. This is especially important when considering the difficulty of managing resources across conventional sectoral silos. Finally, the case highlights the importance of ASM as a location for individuals looking to diversify their livelihoods. This appears particularly stark when contrasted with the juxtaposing tourism industry which appears poorly integrated with the wider economy in the town.

\section{Acknowledgement}

The author wishes to thank Atta for his assistance with the fieldwork, Prof. Hilson for his guidance and support, all the participants and two anonymous reviews for their helpful comments on earlier drafts of this paper. An earlier version of this paper was presented at the African Studies Association UK Biennial Conference 2012. The research was funded by a NERC-ESRC interdisciplinary PhD studentship.

\section{References}

Addo-Fening, R. 2008. The Relevance of Traditional Governance, in: B. Agyeman-Duah (Ed.) Ghana Governance in the Fourth Republic, The Ghana centre of Democratic Development, Digibooks, Tema, Ghana, pp. 32-56.

Aryee, B.N.A. 2001. Ghana's mining sector: its contribution to the national economy. Natural Resources Forum. 27, 61-75.

Ayensu, E. 1997. Ashanti Gold - The African Legacy f the World's Most Precious Metal. Ashanti Goldfields Company Ltd, Marshall Edition, London. 
Baah-Boateng, W. 2004. Employment policies for sustainable development: the experience of Ghana. Paper presented at a national workshop on an employment framework for Ghana's poverty reduction strategy organised by government of Ghana/UNDP/ILO. UNDP <

http://sdnhq.undp.org/content/dam/aplaws/publication/en/publications/povertyreduction/poverty-website/employment-policies-for-sustainable-development-the-experience-ofghana/EmploymentPoliciesForSustainableDev.pdf> (accessed 7.01.12).

Banchirigah, M. 2006. How have reforms fuelled the expansion of artisanal mining? Evidence from sub-Saharan Africa. Resources Policy. 31, 165-171.

Banchirigah, M. 2008. Challenges with eradicating illegal mining in Ghana: A perspective from the grassroots. Resources Policy. 33, 29-38.

Banchirigah, M., Hilson, G., 2009. De-agrarianization, re-agrarianization and local economic development: Re-orientating livelihoods in African artisanal mining communities. Policy Sciences, 43, 157-180.

Barrett, C.B., Reardon, T., Webb, P., 2001. Nonfarm income diversification and household livelihood strategies in rural Africa: concepts, dynamics, and policy implications. Food Policy. 26, 315-331.

Boafo-Arthur, K., 2000. The political economy of Ghana's foreign policy: past, present and future. Ghana Social Science Journal. 1, 1-33.

Bose-O'Reilly, S., Drasch, G., Beinhoff, C., Tesha, A., Drasch, K., Roider, G., Taylor, H., Appleton, D., Siebert U., 2010. Health assessment of artisanal gold miners in Tanzania. Science of The Total Environment. 408, 796-805.

Bryceson, D. F. 1996. De-agrarianization and rural employment in sub- Saharan Africa: A sectoral perspective. World Development. 4, 97-111.

Bryceson, D.F. and Jønsson, J.P. Gold Digging Careers in Rural East Africa: Small-Scale Miners' Livelihood Choices. World Development. 38, 379-392.

Clifford, M., 2012. Pork knocking in the land of many waters: Artisanal and small-scale mining (ASM) in Guyana. Resources Policy. 36, 354-362.

Daily Graphic., 2011. National Security To Stop Sand Winning. Available online: http://www.ghanaweb.com/GhanaHomePage/NewsArchive/artikel.php?ID=223257 (last accessed: 08.01.12)

Denney, L. 2013. Liberal Chiefs or Illiberal Development? The Challenge of Engaging Chiefs in DFID's Security Sector Reform Programme in Sierra Leone. Development Policy Review. 31, 5-25.

Dondeyne, A., Ndunguru, E., Rafael, P., Bannerman, J., 2009. Artisanal mining in central Mozambique: Policy and environmental issues of concern. Resources Policy. 34, 45-50.

Ghana News Agency., 2012. Sand winning is destroying the coast of Central Region. Available online: <http://www.ghanaweb.com/GhanaHomePage/NewsArchive/artikel.php?ID=223257> (last accessed 08.01.12) 
Ghana Statistical Service., 2010. Newsletter - Revised Gross Domestic Product (GDP) Estimates for 2009. Available online:

<http://www.statsghana.gov.gh/docfiles/GDP/Revised\%202009\%20GDP\%20Estimate\%20NEWSLETT ER.pdf> (last accessed: 20.12.12)

Global Mercury Project., 2006. Environmental and Health Assessment report - Removal of barriers to the introduction of cleaner artisanal gold mining and extraction technologies. Available online:

$<$ http://www.globalmercuryproject.org/documents/non country\%20specific/GMP-EHA-

Final Report-July24-06.pdf> (last accessed 21.12.2012).

Grant, J.A., Mitchell, M.I., Nyame, F.K. 2011. New regionalisms, micro-regionalisms, and the migration-conflict nexus: evidence from natural resource sectors in West Africa. In: Shaw, T.M., Grant, J.A., Cornelissen, S. (Eds.), The Ashgate Research Companion to Regionalisms. Ashgate, Aldershot, 375-396.

Hentschel, T., Hruschka, F., Priester, M., 2002. Global Report on Small-Scale and Artisanal Mining. Mining Minerals and Sustainable Development - a project of the International Institute for Environment and Development (IIED), London.

Hilson, G., 2002. Harvesting mineral riches: 1000 years of gold mining in Ghana. Resources Policy. 28, 13-26.

Hilson, G. ,2007. What is wrong with the Global Support Facility for small-scale mining? Progress in Development Studies. 7, 235-249.

Hilson, G., 2009. Small-Scale Mining, Poverty and Economic Development in Sub-Saharan Africa: An Overview. Resources Policy. 34, 1-5.

Hilson, G., 2010. 'Once a Miner, Always a Miner': Poverty and Livelihood Diversification in Akwatia, Ghana. Journal of Rural Studies. 26, 296-307.

Hilson, G. 2012a. Family work and cultural values: Child labor in Malian artisanal gold mining communities. World Development. 40, 1663-1674.

Hilson, G., 2012b. Poverty traps in small-scale mining communities: The case of sub-Saharan Africa. Canadian Journal of Development Studies. 33, 180-197.

Hilson G., Banchirigah S., 2009. Are Alternate Livelihood Projects Alleviating Poverty in Mining Communities? Experiences from Ghana. Journal of Development Studies. 45, 172-196.

Hilson, G., Garforth, C.J. 2012., 'Agricultural Poverty' and the Expansion of Artisanal Mining: Case studies from West Africa. Population Research and Policy Review. 31, 435-464.

Hilson, G., Maponga, O., 2004. How has a shortage of census and geological data impeded the regularization of artisanal and small-scale mining? Natural Resources Forum. 28, 22-33.

Hilson, G., Potter, C., 2003. Why Is Illegal Gold Mining Activity so Ubiquitous in Rural Ghana? African Development Review. 
Hilson, G. Potter, C. 2005. Structural Adjustment and Subsistence Industry: Artisanal Gold Mining in Ghana. Development and Change. 36, 103-131.

Hirons, M. 2013. Mining in Ghana's forests: cross-sectoral linkages and the prospects for REDD. International Development Planning Review. 35, 283-302.

Hutchful, E., 2002. Ghana's Adjustment Experience: The Paradox of Reform. Oxford University Press for UNRISD, Oxford.

Koutra, C., Edwards, J., 2012. Capacity Building through Socially Responsible Tourism Development: A Ghanaian Case Study. Journal of Travel Research. 51, 777-792.

Kumar R., and Amaratunga D., 1994. Government policies towards small-scale mining. Resources Policy. 20, 15-22.

International Labour Organisation (ILO)., 1999. Tripartite Meeting on Social and Labour Issues in Small-scale Mines - Note on the proceedings. ILO, Geneva.

Martinez-Alier, J., 2001. Mining conflicts, environmental justice, and valuation. Journal of Hazardous Materials. 86, 153-170.

Mee, L., Dublin, H., Eberhard, A., 2008. Evaluating the Global Environment Facility: A goodwill gesture or a serious attempt to deliver global benefits? Global Environmental Change. 18, 800-810.

Nyame, F.K. and Blocher, J., 2010. Influence of land tenure practices on artisanal mining activity in Ghana. Resources Policy. 35, 47-53.

Nyame, F.K., Grant, J.A., 2012. From carats to karats: Explaining the shift from diamond to gold mining by artisanal miners in Ghana. Journal of Cleaner Production. 29, 163-72.

Nyame, F.K., Grant, J.A., Yakovleva, N., 2009. Perspectives on migration patterns in Ghana's mining industry. Resources Policy. 34, 6-11.

Ofosu-Mensah, E.A., 2011. Historical overview of traditional and modern gold mining in Ghana. International Research Journal of Library, Information and Archival Studies. 1, 6-22.

Owusu-Darlington, S., Dapaah, D., 2011. Mad Rush For Gold at Elmina. Daily Guide Newspaper <http://www.dailyguideghana.com/?p=33304> (last accessed: 19.12.12).

Silver, J., 1981. The Failure of European Mining Companies in the Nineteenth-Century Gold Coast. The Journal of African History. 22, 511-529.

Teschner, B., 2012. Small-scale mining in Ghana: the government and the galamsey. Resources Policy. 37, 308-314.

Tetteh, K., 2012. An Overview of Ghana's Artisanal and Small Scale Mining (ASM) Sector. Government of Ghana, Minerals Commission. http://www.ghanamining.org/GhanaIMS/LinkClick.aspx?fileticket=lcrOe\%2fV5DFA\%3d\&tabid=36\&mid=930 (last accessed: 21.02 .13$)$ 
Teye, V., Sönmez, S., Sirakaya, E., 2002. Resident Attitudes toward Tourism Development. Annals of Tourism Research. 29, 668-688.

Tschakert, P., Singha, K., 2007. Contaminated identities: Mercury and marginalization in Ghana's artisanal mining sector. Geoforum. 38, 1304-1321.

Tschakert, P., 2009. Recognizing and nurturing artisanal mining as a viable livelihood. Resources Policy. 34, 24-31.

Ubink, J.M., Quan, J.F., 2008. How to combine tradition and modernity? Regulating customary land management in Ghana. Land Use Policy. 25, 198-213.

Water Resources Commission of Ghana,. 2011. Galamsey at Elmina. <http://wrcgh.org/en/news/11/galamsey-at-elmina > (last accessed 17.12.12). 